\title{
Exam Preparation Strategies and Concerns of University Students: Gender and Open Access Vs Regulated System Effects
}

\author{
Ilham Zerdani ${ }^{1}$, Said Lotfi ${ }^{2}$ \\ ${ }^{I}$ Department of Biology. Laboratory of Ecology and Environment (LEE). Faculty of Sciences, Hassan II University of Casablanca, \\ BP 50069, Ghandi, Morocco \\ ${ }^{2}$ Multidisciplinary Loboratory in Educations Sciences and Training Ingeneering (LMSEIF). Sport Science Assessment and Physical \\ Activity didactic. Normal Superior School (ENS), Hassan II University of Casablanca, BP 50069, Ghandi, Morocco
}

\begin{abstract}
The purpose of this study is to identify test preparation strategies and concerns of university students in the open and regulated education system. We surveyed 294 students (55.10\% male, $44.90 \%$ female), $60.54 \%$ from the open access system, and 39. $46 \%$ from the regulated access system, four dimensions are measured: students' and parents' concerns about university education, constraints to effective academic performance, exam preparation strategies and factors affecting academic performance.

The results show three main student concerns in both training systems: self-development, seeking new learning (84.35\%) and graduation $(73.13 \%)$. On the other hand, about half of the students $(49.32 \%)$ feel that their parents are preoccupied with their studies and are stressed or bothered (31.29\%) by their incessant advice. We have identified 15 types of difficulties that are sources of constraint on the efficiency of university student performance, grouped into three categories: cognitive difficulties (32.64\%), teaching methods difficulties (30.57\%) and organization difficulties of the training program (36.79\%). One-fifth of students review every day, every course, and thus spend an average of half an hour to an hour (41\%) per review day. However, female students spent significantly more time per day $(+3$ hours, $p<.038)$ on course revision than their male colleagues. Analysis of students' exam preparation programs shows six preparation strategies, dominated by the reading method $(28.90 \%)$ and course outlines $(26.30 \%)$. In both training systems, half of the students were dissatisfied (52.38\%) with their personal preparation methods, of which $71.22 \%$ were female students. These students also perceive that their exam review strategies are little or not effective $(56.46 \%)$ of which $40.22 \%$ are female students significantly different from their male counterparts $(\mathrm{p}<.05)$. The majority of students $(61.88 \%)$ in both training systems do not place importance on all training modules. This finding is more pronounced for males than females $(40.51 \% \mathrm{vs} 21.27 \%$, $\mathrm{p}<.008$, respectively), and higher in the OSA than in the RAS $(46.41 \%, 15.47 \%, \mathrm{p}<.008$, respectively). The bivariate correlation analysis shows significantly positive coefficients between 1 st and 2 nd year university results year university $(\mathrm{r}=.428, \mathrm{p}<, 000)$, and baccalaureate 's marks $(\mathrm{r}=.255$, $\mathrm{p}<.019$ ). We also identified five factors responsible for poor school grades. It is necessary to introduce cognitive and mental preparation approaches for students into the pedagogical system of university teaching and supervision in order to optimize the performance of students' results.
\end{abstract}

Keywords: Strategies for preparation, Exams, Concerns, Academic Outcomes, Open access, Regulated system.

\section{INTRODUCTION}

The literature has amply demonstrated that success in examinations and entrance exams depends on the complex interplay of several factors: socio-demographic, pedagogical, previous schooling, cognitive, motivational, affective and personal characteristics, as well as contextual elements such as the cultural and family environment. The positive outcome of these interactions is crucial in achieving higher academic outcomes [1]. However, the main factors contributing to academic achievement also remain ambiguous and, to date, admit numerous explanations from various fields such as genetics, sociology, psychology, cognitive neuroscience, and pedagogy [2-4].
A revision strategy in a school context is the implementation of cognitive and metacognitive actions used in a situation of learning and consolidation of knowledge. It is oriented with the aim of carrying out an activity that serves to perform operations on knowledge according to specific objectives. Revision strategies are activities performed by the learner to facilitate the acquisition, storage, recall and application of knowledge at the time of learning [5].

In the literature, the most successful students are those who are able to manage with a high percentage of effectiveness at the level of logical thinking, rapid learning, comprehension, memorization, perseverance, concentration, deduction, abstraction, generalization, synthesis, writing, and morale. Studies have identified that 
preparation time, number of repetitions, and mental stamina as key elements of effective review strategies for university exams [6-10]. Other works has shown that emotional attractiveness and the degree of motivation for learning [11] the desire to know [12] and emotional control [13] more qualify the subject to solve educational problems and overcome learning barriers. However, few studies have focused on the impact of exam preparation and entrance exams [14]: it has been shown that students' reaction and stress levels are high during university life and especially during exam preparation $[15,16]$.

In recent years, several literature reviews have emphasized the important positive impact of environmental factors on academic outcomes: parental involvement [1721], family socio-economic level [22] and academic support structures: library, accommodation, food, extracurricular activities and university culture...etc [23].

The university reforms (known as the LMD reform) initiated in 2003 in the Moroccan higher education focused on improving the system, supply, and quality of training. The structure of the education system in Morocco is made up of public universities $(78.4 \%)$, private higher education institutions ( $4.4 \%)$, executive training institutions ( $2.9 \%)$ and post-baccalaureate vocational training institutions (14.3\%). The 56 open-access institutions accounted for more than $87.6 \%$ of the university's students, while the 68 regulated-access institutions accounted for only $12.4 \%$. The two systems (regulated and open) are by no means equivalent channels for determining the flow of students into and out of higher education. In fact, they follow a strict hierarchical logic.

The regulated system receives the best students on the basis of their baccalaureate grade and the passing grade in a competitive examination. This selection makes it possible to extract the best students, and thus drive the majority of the remaining flow to the open system. This horizontal selection results in a dichotomy between "the best" and "the worst". It is the open system that has the highest dropout rate $(47.2 \%)$ and the highest rate of recurring student absenteeism due to its open nature. Continuing to study in open-access faculties is considered to be the last resort for students who have not been able to access selective-access institutions.

The exams are an integral part of the student's university experience, who passes no less than 48 evaluation situations per year (tests and exams).Upon entering university studies, students are deprived of effective methods and strategies for success and very rarely those who validate all the modules of the program without compensation, despite the introduction of the module "methodology of work at the university". Observation of the Moroccan reality shows that the continuous revision of the program modules is often neglected by students. Exam preparations are done only one to two weeks in advance, and are often done too intensively, with rushed readings, superficial understandings, poorly mastered knowledge, and skipped chapters. On the day of the exam, faced with 6 modules, the student can only be distraught, stressed, and loses self-confidence. The purpose of this study is to identify test preparation strategies and concerns of university students in the open and regulated education system.

\section{METHODOLOGY}

\section{A. Subjects}

We interviewed a sample of 294 students including 162 males $(55,10 \%)$ and 132 females $(44.90 \%)$, aged $21.30 \pm$ 0.57 years old belonging to two establishments of Hassan University of Casablanca: $60.54 \%$ (178) of the students continue their studies in the 3rd year in the Life Sciences Stream, at the Ben M'Sick Faculty of Sciences (open access system), and $39.46 \%$ (116) at the Higher Teacher Training College in the Life Sciences Stream-Education, (regulated access system) and are selected on the basis of a preselection on the marks of the baccalaureate and a competitive examination.

\section{B. Measuring instruments}

The survey is conducted in parallel in the training systems (open access vs. regulated access) of the respondents, using a structured questionnaire in five dimensions:

- Concerns of students (6 items) and parents (4 items),

- Revision strategies and preparation modalities for university exams ( 8 items and 1 Open-ended item),

- Perception of the exams: difficulty of the exams (1 item) and importance of the training modules (1 item), factors explaining the positive and negative results (2 Open-ended items),

- Constraints to efficient university performance (1 open-ended item).

- Academic results in the form of grades and module validation (4 parameters), are obtained from schooling services.

Measurements are made on a 4-level Likert scale: strongly disagree (1), strongly agree (4). We also collected data on gender (male vs. female). The survey is conducted just after the 3rd year Bachelor's degree exams.

\section{Data Analysis}

The data from the dependent variables: student and parent concerns, university exam preparation modalities, exam difficulty and importance of training modules, are presented in frequencies and percentages and analyzed by Khi2 test and independent Student's $t$ test to assess the effects of gender, training system, preparation and academic grades. The analysis of the relationships between academic results (expressed in grades and number of validated modules) is carried out by calculating the Bravais-Pearson correlation coefficient, $\mathrm{p}$ is set at 0.05 . 
The data obtained from the open-ended questions are processed using the thematic content analysis technique, so that the themes that emerge are present in frequencies and percentages [24].

\section{RÉSULTS}

\section{A. Student and parental concerns about university}

\section{1) Student concerns about the university space}

The results in Table 1 show that half of the students perceive a general interest in several components of university life expressed in widely varying percentages. In both training systems, the three main concerns are : selfdevelopment, seeking new learning (84.35\%) and graduation $(73.13 \%)$. Nevertheless, $14.29 \%$ of the students in the open access institution show a lack of interest in their studies and consider them a transitional phase in which to reorient themselves.

However, we have noted that this interest is significantly differentiated between the two sexes, with $44.9 \%$ of females defining their first concern in the search for a degree. While among males, this percentage is limited to $34.6 \%(\mathrm{p}<.000 ; \mathrm{kh} 2=18.409)$.

Female students also show more quest for good grades in exams (Khi 2=8,856, $\mathrm{p}<.003$ ), and friendship (Khi
$2=6.864, \mathrm{p}<.009)$ than their male counterparts respectively $36.6 \%$ vs. $31.7 \% ; 30.8 \%$ vs. $25.9 \%$.

The concerns of students from both training systems vary significantly $(\mathrm{p}<.000)$, towards the university space. Thus, $45.3 \%$ of OAS students (Khi2 $=17.062, \mathrm{p}<.000$ ) are looking for more degrees and good grades $(60.3 \%$, chisquare: $6.800, p<.009)$, than those in the regulated access system ( $8.2 \%$ and $34.4 \%$, respectively).

\section{2) Student concerns and parental expectations}

Half of the parents expect good university results, and express concerns about their behaviours during university training such as absence, revisions, passing exams (Table 1). On the other hand, about half of the students $(49.32 \%)$ feel that their parents are preoccupied with their studies and are stressed or bothered $(31.29 \%)$ by their incessant advices.

In particular, these parental concerns are manifested more significantly $(\mathrm{p}<.05)$ among OAS students $(67.7 \%$, relative percentage) than SAR students (32.3\%) and among female students $(60 \%$ in terms of needs, $85.55 \%$ in terms of behaviours). We also found that the more parents expect good results from their children, the more their children look for new learning $(70 \%)$ and friends $(31.5 \%)$ in the university space.

TABLE I. VARIATION IN ACADEMIC CONCERNS AND OUTCOMES TOWARD THE UNIVERSITY AND FAMILY SPACE.

\begin{tabular}{|c|c|c|c|c|c|c|}
\hline \multirow[b]{2}{*}{ Parameters } & \multirow[b]{2}{*}{$\%(n)$} & \multicolumn{5}{|c|}{ Effect $(p)$} \\
\hline & & $\begin{array}{l}\text { Gender } \\
(p)^{a}\end{array}$ & $\begin{array}{l}\text { Training system } \\
(p)^{a}\end{array}$ & $\begin{array}{l}\text { Exam preparation } \\
(p)^{a}\end{array}$ & $\begin{array}{l}\text { Academic grades } \\
(p)^{b}\end{array}$ & $\begin{array}{l}\text { Parents } \\
(p)^{a}\end{array}$ \\
\hline \multicolumn{7}{|l|}{ Concerns about the university space. } \\
\hline Seek new leearning & $\begin{array}{l}84.35 \% \\
(248)\end{array}$ & ns & ns & ns & ns & 0.047 \\
\hline Self-development & $\begin{array}{l}73.13 \% \\
(215)\end{array}$ & ns & ns & ns & ns & ns \\
\hline Obtaining the diploma. & $\begin{array}{l}68.71 \% \\
(202)\end{array}$ & .000 & .000 & .019 & .020 & ns \\
\hline Getting good grades & $\begin{array}{l}67.35 \% \\
(198)\end{array}$ & .003 & .009 & .013 & .001 & .046 \\
\hline Search for friendship & $\begin{array}{l}56.12 \% \\
(165)\end{array}$ & .009 & & & & \\
\hline Disinterest in academic studies. & $\begin{array}{l}14.29 \% \\
(42)\end{array}$ & ns & .005 & .007 & .007 & ns \\
\hline \multicolumn{7}{|l|}{ Concerns about parents } \\
\hline Students' demands on their parents & $\begin{array}{l}28.91 \% \\
(85)\end{array}$ & .005 & .005 & ns & .047 & - \\
\hline $\begin{array}{l}\text { Parents' concerns about their son's } \\
\text { behaviour }\end{array}$ & $\begin{array}{l}49.32 \% \\
(145)\end{array}$ & .000 & .000 & ns & .048 & - \\
\hline $\begin{array}{l}\text { Parents' concerns about academic } \\
\text { performance, }\end{array}$ & $\begin{array}{l}50.34 \% \\
(148)\end{array}$ & ns & ns & ns & .033 & - \\
\hline Parents stressing their sons. & $\begin{array}{l}31.29 \% \\
(92)\end{array}$ & ns & ns & ns & .006 & - \\
\hline
\end{tabular}

a: Comparison by Khi2 test, $p<0.05, b$ : $b$ : comparison by independent Student's t test, $p<0.05$, 


\section{B. Constraints to efficiency of academic performance perceived by students.}

The difficulties encountered by students during their university education are presented in terms of frequency and percentage in Table 2.

We have identified 15 types of difficulties that are sources of constraint on the efficiency of university student performance, grouped into three categories:

Students' cognitive difficulties (32.64\%) are expressed by insufficient prior knowledge, lack of continuous preparation and organization of work at home, difficulties in cognitive knowledge management related on the one hand to poor understanding of the language (vocabulary and discourse) and difficulties in assimilating content, and on the other hand to difficulties in memorization, reasoning and concentration.

Difficulties related to teaching methods (30.57\%) are related to insufficient explanations, ineffective teaching methods, disorganized lesson plans, practical examples and insufficient course materials. The questions and grading scales of the exams are poorly adapted to the real level of the students.

Difficulties related to the organization of the training program $(36.79 \%)$ are expressed by condensed timetables, overloaded programs, an unfavorable climate in the lecture theaters, and poor distribution of difficult modules.

TABLE II. CONSTRAINTS TO EFFICIENCY OF ACADEMIC PERFORMANCE PERCEIVED BY STUDENTS.

\begin{tabular}{lcc}
\hline Constraints & Frequency & Percentage \\
\hline $\begin{array}{l}\text { Absence or poor explanation of } \\
\text { courses, }\end{array}$ & 150 & 18.82 \\
Overloaded courses, & 131 & 16.44 \\
$\begin{array}{l}\text { Disorganized pedagogical methods } \\
\text { and course plans, }\end{array}$ & 95 & 11.92 \\
$\begin{array}{l}\text { Difficulty in understanding courses, } \\
\text { Insufficient basic knowledge, }\end{array}$ & 85 & 10.67 \\
$\begin{array}{l}\text { Poor quality of course materials } \\
\text { handouts), }\end{array}$ & 74 & 9.29 \\
Condensed curriculum, & 55 & 6.90 \\
$\begin{array}{l}\text { Poor organization of work at home, } \\
\text { insufficient ongoing preparation, }\end{array}$ & 42 & 5.27 \\
$\begin{array}{l}\text { Difficulty in memorization } \\
\text { Difficult and complicated courses, }\end{array}$ & 35 & 4.39 \\
$\begin{array}{l}\text { Difficulty in concentrating, } \\
\text { Insufficient practical examples in the }\end{array}$ & 27 & 3.76 \\
lessons & 15 & 3.39 \\
$\begin{array}{l}\text { Difficulty in reasoning } \\
\text { Unfavorable climate in the lecture }\end{array}$ & 14 & 1.86 \\
hall, & 12 & 1.51 \\
Questions and grading systems in the & 11 & 1.38 \\
exams are poorly adapted, & 797 & 100.00 \\
\hline Total items & & \\
\hline
\end{tabular}

\section{Strategies for reviewing courses and preparing for} continuous control and final exams.

1) Schedules, frequency and volume of university exam preparation.

One-fifth (19.73\%) of students review every day, every course, and thus spend an average of half an hour to an hour (41\%) per review day. However, female students spent significantly more time per day $(+3$ hours, $\mathrm{p}<.038)$ on course revision than their male colleagues.

Almost all students (90.47\%) do not begin their preparation for the Continuous Assessment until the last week, with $41.2 \%$ beginning just one day before the Continuous Assessment.

Whereas for the final exam of the semester, the majority of students $(84.35 \%)$ only began their preparation in the last two weeks before the exam, $34.7 \%$ of whom started just one week before. Particularly OAS students significantly $(\mathrm{p}<.05)$ begin their preparation before those of RAS.

TABLE III. EXAM PREPARATION AND COURSE REVIEW ACCORDING TO GENDER AND TRAINING SYSTEM.

\begin{tabular}{|c|c|c|c|c|}
\hline \multirow[b]{2}{*}{ Parameters } & \multirow{2}{*}{$\begin{array}{c}\%(n) \\
\text { Mean } \\
\pm \mathrm{sd}\end{array}$} & \multicolumn{3}{|c|}{ Effect } \\
\hline & & $\begin{array}{l}\text { Gender } \\
(p)^{a}\end{array}$ & $\begin{array}{c}\text { Training } \\
\text { System }(p)^{a}\end{array}$ & $\begin{array}{c}\text { Academic } \\
\text { Grades }(p)^{b}\end{array}$ \\
\hline $\begin{array}{l}\text { Daily review of } \\
\text { courses }\end{array}$ & $\begin{array}{c}19.73 \% \\
(58)\end{array}$ & .038 & .000 & .036 \\
\hline $\begin{array}{l}\text { Beginning of } \\
\text { preparation for }\end{array}$ & $\begin{array}{l}90.47 \% \\
(266)\end{array}$ & ns & ns & ns \\
\hline
\end{tabular}

continuous tests

week before.

Preparation for $\quad 84,35 \% \quad$ ns $\quad .000 \quad .000$

exams 2 weeks

before.

Hourly volume

(248)

$6.55 \mathrm{hr}$

$\pm 3,90$

017

.000

per day of exam

preparation (one

week before the

exam)

Unfavorable

conditions for

review.

Satisfaction with

exam preparation

methods

Effectiveness of

exam preparation

methods.

Importance given

to courses.

Difficulty level of

$71.09 \%$

ns

.001

ns

$47.62 \%$

.009

.001

ns

(140)

$43.54 \%$

.07

.001

.008

(128)

the exams

$38.12 \%$

(115)

$76.87 \%$

ns

.047

$.017^{\mathrm{NVC}}$

(226)

a: comparison by Khi 2 test, $b$ : comparison by independent Student's $t$ test, $p<0.05$, NVC: Number of validated courses,

During the last week before the exam, students spend an average of $6.55 \pm 3.90$ hours per day. This hourly volume increases significantly $(\mathrm{p}<.05)$ to $8.58 \mathrm{hr} \pm 4.26$ per day for OAS students $(69.23 \%)$ compared to RAS students $(4.27 \pm 2.80)$. Female students spend significantly $(\mathrm{p}<.017)$ more time per day $(+1.30 \mathrm{hr})$ than males. 
The majority of students $(71.09 \%)$ consider the conditions under which they review their courses to be unfavourable and thus prefer to prepare in their university residence $(85.7 \%)$. These conditions are not significantly the same as for RAS students.

\section{2) Exam preparation strategies}

The quantitative and qualitative data regarding course review and final exam preparation strategies are presented in Table 4, respectively. The results are expressed as frequencies in the form of a double entry matrix.

We structure the results of the preparation practices adopted by students into three aspects: preparation methods, the number of modules to be prepared per day, and the daily timetable organization.

In relation to the preparation methods. The students during the pre-examination period at the end of the semester, declare to establish relatively a personal preparation program designed according to the nature and difficulty of the module, the preferred working methods, the time reserved, the period of the day, and the number of days available.

Analysis of students' exam preparation programs shows six preparation strategies (Table 4), of which two are dominant $(55.15 \%)$ : reading $(28.88 \%)$ and summarise the courses $(26.27 \%)$. They are combined in very different proportions for each student. In relation to the number of modules to be prepared per day, we noted two modalities adopted by the students: a modality of parallel preparation of 3-4 modules per day, which is observed mainly among female students $(79.55 \%)$, and a modality of serial preparation, adopting a single module for 1-3 days.

With regard to the daily timetable for exam preparation, we also noted two methods adopted by the students: an alternative approach between work and rest with periods of 30 min-2 hours, and an intensive strategy during the whole day or all night (sleepless night) observed mainly among males $(76.68 \%)$.

TABLE IV. STRATEGIES FOR COURSE REVIEW AND UNIVERSITY EXAM PREPARATION.

\begin{tabular}{|c|c|c|c|}
\hline Strategies & Percentage & Frequency* & Description \\
\hline Reading and understanding of courses & 28.88 & 199 & $\begin{array}{l}\text { Repeated readings ( } 2-3 \text { times } / 30-45 \mathrm{mn}) \text {. } \\
\text { General reading then in-depth. }\end{array}$ \\
\hline Summarise the courses & 26.27 & 181 & $\begin{array}{l}\text { Rewriting courses in your own style. } \\
\text { Use of lecture notes, } \\
\text { Highlighting key concepts, } \\
\text { Schematizing knowledge. }\end{array}$ \\
\hline Work in a group & 16.98 & 117 & $\begin{array}{l}\text { Review in group of } 2 \text { to } 4 \text { students. } \\
\text { Mutual explanations of lessons and exercises. }\end{array}$ \\
\hline Memorize & 14.66 & 101 & Learn by heart the most important knowledge \\
\hline Solving exercises & 7.69 & 54 & $\begin{array}{l}\text { Review of previous exams and application exercises. Practice on } \\
\text { new exercises. }\end{array}$ \\
\hline Readings of complementary documents & 5.08 & 36 & - \\
\hline
\end{tabular}

* The first 3 choices expressed.

\section{c. Satisfaction and effectiveness of exam preparation strategies}

The satisfaction and effectiveness with the preparation strategies adopted by students are presented in Tables 1 and 4.

In both training systems, half of the students were dissatisfied $(52.38 \%)$ with their personal preparation methods, of which $71.22 \%$ were female students. These students also perceive that their exam review strategies are little or not effective (56.46\%) of which $40.22 \%$ are female students significantly different from their male counterparts $(\mathrm{p}<.05)$.

The OSA students report being very dissatisfied and less effective in their preparation methods than RAS students $28.6 \%$ vs. $23.8 \%$ and $30.6 \%$ vs. $25.9 \%$, respectively $(\mathrm{p}<.05)$.
We noted that students who consider their preparation methods to be effective are those who significantly ( $\mathrm{F}=$ $7,482, \mathrm{p}<.008$, stat $=.56$ ) validate more modules per semester, compared to other students respectively $+35.66 \%$ in 1 st year and $+47.87 \%$ in 2 nd year (validated modules).

Similarly, students who are satisfied with their preparation methods have fewer modules below the 10/20 mark in 1st and 2nd year of university education, respectively $-20.31 \%$ and $-31.09 \%$ validated module.

\section{Factors affecting academic performance}

1) Effect of the importance attributed to the modules and the exam difficulty on the academic results.

The results of the importance placed on program modules and the difficulty of the exams are presented in Table 1.

The majority of students $(61.88 \%)$ in both training systems do not place importance on all training modules, 
with few modules retaining only their interest. This finding is more pronounced for males than females $(40.51 \% \mathrm{vs}$. $21.27 \%, \mathrm{p}<.008$, respectively), and higher in the OSA than in the RAS $(46.41 \%, 15.47 \%, \mathrm{p}<.008$, respectively).

As a result, 76.80 per cent of students felt that the degree of difficulty of all modules exceeded their abilities, thus declaring the requirements requested were considered unattainable. This dual finding (degree of importance and difficulty) is significantly more observed in the OAS than in the SAR $(\mathrm{p}<.05)$.

We also noted in the first two years that students who gave high importance to all modules at the same time and considered the exams to be difficult in relation to their abilities were those who significantly $(p<.05)$ validated more modules than those who underestimated them (Table 1): $+49.01 \%$ of modules validated/high importance, $+2.82 \%$ /perceived exam difficult.

We observed that the more concerned students were about obtaining a diploma (khi2=11.682, $\mathrm{p}<.019)$, and good grades $(\mathrm{khi} 2=6.98, \mathrm{p}<.013)$, the earlier they started their exam preparation $(42.2 \%$ vs. $6.3 \%)$ and validated more modules per year: $6 / 6$ validated modules. one month and more of preparation, $5.43 \pm 1.5$ validated modules / one week of preparation before the exam.

\section{2) Academic outcomes correlations}

The correlation matrices between baccalaureate grades and the first two years of university and their factors of variation are presented in Table 5.

The bivariate correlation analysis shows significantly positive coefficients between 1 st year university results and baccalaureate's marks $(12.38 \pm .08,13.96 \pm .79, \mathrm{r}=.255$, $\mathrm{p}<.019$ respectively) and 2 nd year university results $(\mathrm{r}=$ $.428, \mathrm{p}<, 000)$, however the intensity of its coefficients remains medium.
We also observed negative correlations between the number of non-validated modules and baccalaureate results $(\mathrm{r}=-.265), 1 \mathrm{st}(\mathrm{r}=-.464)$ and $2 \mathrm{nd}$ academic year results $(\mathrm{r}=$ $-.342)$.

We observed that the average marks of female students are significantly $(\mathrm{p}<.05)$ higher than those of males: $+15.85 \%$ in the baccalaureate, $+12.13 \%$ in 1 st year; $+21.33 \%$ in 2 nd year.

TABLE V. PREPARATION OF EXAMINATIONS AND REVISION OF COURSES ACCORDING TO GENDER AND TRAINING SYSTEM.

\begin{tabular}{|c|c|c|c|}
\hline \multirow{2}{*}{$\begin{array}{l}\text { Academic grades } \\
\text { (20-point) }\end{array}$} & \multirow[b]{2}{*}{$\begin{array}{c}\text { Mean } \\
\pm S d\end{array}$} & \multicolumn{2}{|c|}{ Effect } \\
\hline & & $\begin{array}{l}\text { Gender } \\
(p)^{a}\end{array}$ & $\begin{array}{c}\text { Training } \\
\text { system }^{b}(p)\end{array}$ \\
\hline Baccalaureate & $13.96 \pm .79$ & .020 & $\mathrm{~ns}$ \\
\hline 1st year of university & $12.38 \pm 1.08$ & .029 & .039 \\
\hline 2nd year of university & $12.77 \pm .971$ & .007 & .032 \\
\hline
\end{tabular}

a: average of the grades of 1 st and t2nd academic year, $p<05$.

$b$ : comparison by independent Student's t test.

It is also noted that the academic results of RAS students are higher than those of OAS students: $+11.47 \%$ in 1 st year, $+12.23 \%$ in 2 nd year (Table 4 ).

Academic scores also increase among students who are more concerned about graduating $(\mathrm{F}=11,682, \mathrm{p}<.020)$, having good grades $(\mathrm{F}=10.77, \mathrm{p}<.001)$, continuously reviewing courses $(p<.036)$ spending more time $(p<.03)$ and preparing for exams early $(\mathrm{p}<.000)$, and having efficient work methods (Table 1).

Thus, students who gave high importance to all modules and considered the exam papers difficult in relation to their abilities were those who significantly validated more modules $(\mathrm{p}<.05)$.

We also observed that students who were disinterested in their studies $(\mathrm{F}=11.56, \mathrm{p}<.007)$, stressed by parental attitudes, had lower academic performance and validated fewer modules (respectively $-58.76 \%,-23.25 \%, \mathrm{p}<.05$ ).

TABLE VI. CORRELATION MATRIX OF ACADEMIC ACHIEVEMENT GRADE FOR THE 1ST YEAR OF UNIVERSITY

\begin{tabular}{|c|c|c|c|c|c|c|}
\hline \multirow[b]{2}{*}{ Parameters } & & \multicolumn{3}{|c|}{ Moyenne des notes } & \multicolumn{2}{|c|}{ Number of courses $<10 / 20$ in 1 st year } \\
\hline & & $\mathrm{Bac}$ & $1^{\text {st }}$ year & $2^{\text {nd }}$ year & $1^{\text {st }}$ year & $2^{\text {nd }}$ year \\
\hline \multirow{2}{*}{$\begin{array}{l}\text { Average grades in the } \\
\text { Baccalaureate (Bac) }\end{array}$} & $r$ & 1 & $.255^{*}$ & .187 & $-.265^{*}$ & -.160 \\
\hline & $p$ & & .019 & .087 & .015 & .145 \\
\hline \multirow{2}{*}{$\begin{array}{l}\text { Average grades in } 1^{\text {st }} \text { year } \\
\text { university }\end{array}$} & $r$ & & 1 & $.428^{* *}$ & $-.464^{* *}$ & -.119 \\
\hline & $p$ & & & .000 & .000 & .282 \\
\hline \multirow{2}{*}{$\begin{array}{l}\text { Average grades in } 2^{\text {nd }} \text { year } \\
\text { university }\end{array}$} & $r$ & & & 1 & $-.342^{* *}$ & $-.575^{* *}$ \\
\hline & $p$ & & & & .002 & .000 \\
\hline \multirow{2}{*}{$\begin{array}{l}\text { Number of courses }<10 / 20 \\
\text { in1st year }\end{array}$} & $r$ & & & & 1 & $.510^{* *}$ \\
\hline & $p$ & & & & & .000 \\
\hline
\end{tabular}

Factors explaining academic outcomes:

Factors explaining students' good and poor grades are presented in Table 5.
Students attribute their good academic results are attributed to the following factors: 
- High level cognitive skills are related to the ability to understand lessons, concentration in class,

- memorization of knowledge.

- Continuous and efficient preparation methods are operationalised by Continuous revision, efficient working method, high interest in lectures and completion of extra work.

- Interest in training courses.

- Sufficient mastery of prior knowledge, related to sufficient command of prior knowledge and language of instruction,

- Adapting the teacher's assessment is an external factor, considering the exam questions as easy and the grading system appropriate and facilitating.
- Poor preparation methods for exams and continuous assessments. (35.10\%) expressed by lack of knowledge about effective methods and insufficiency of continuous preparation.

- Weakness of certain cognitive skills $(28.15 \%)$ in memorization, concentration and comprehension.

- Teachers' assessments are poorly matched to the level of difficulty in exam questions and in the grading scales.

- Disinterest in training courses and low self-esteem $(12.25 \%)$ :

- Weakness of prior knowledge at the level of the prerequisites and language., (10.79\%).

While poor academic grades to five factors:

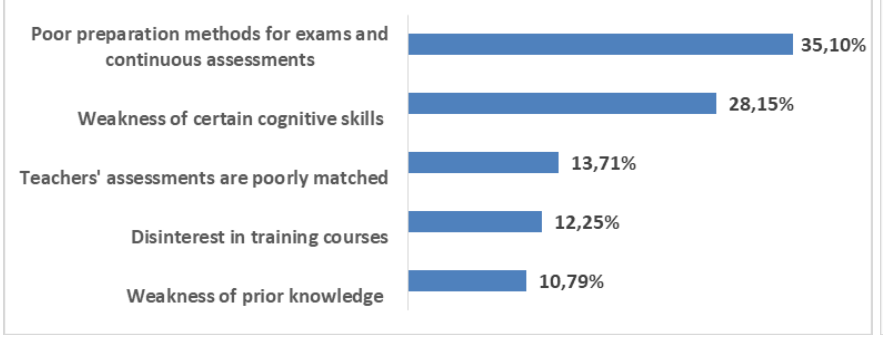

POOR GRADES ACADEMIC RESULTS

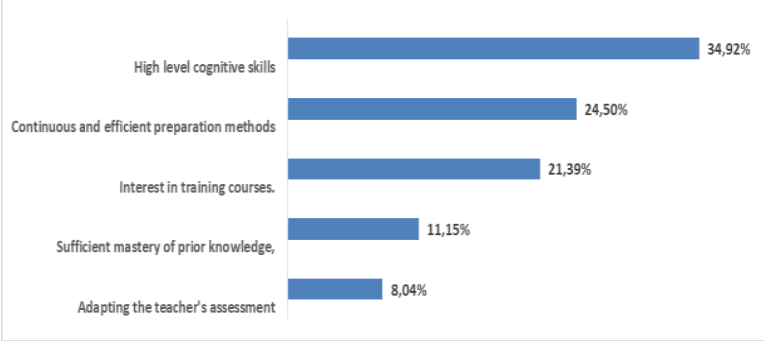

GOOD ACADEMIC RESULTS

Figure 1. Factors explaining students' academic grades. Data are presented in terms of frequencies and percentages.

\section{DISCUSSION}

The aim of this study was to identify exam preparation strategies and concerns of university students with respect to the open and regulated university education system. Our results showed three main concerns of students in the university space: self-development, learning from new things, and the search for degrees. However, we noticed that this interest is significantly differentiated between the two genders. Female students are more concerned about obtaining a degree and seeking good grades in exams. The concerns of students from both education systems vary significantly towards the university space. It is also noted that in both training systems, the majority of students do not attach importance to all training modules.

This finding is more pronounced among boys than girls and higher in the OAS. The majority of students in this training system feel that the demands of the modules are beyond their abilities. These results can be explained by the student's motivation expressed by his need to succeed and perform, unlike students who are always fighting to avoid failure [25]. There are about ten studies that have shown high correlations between motivation and academic results [25], to which is added the relevant role of post- baccalaureate orientation. The absence of these 2 factors is the source of massive drop-out in the first academic year. Thus, the levels of ambition to which the student aspires during his university education determine his psychological driving force that pushes him to reach objectives, to put in place means of action and to overcome obstacles [26]. This is why, in the two university systems in which we conducted our survey, $10 \%$ of OAS students complete their university education in 3 years, while $95 \%$ do so at the RAS level. These two systems operate globally in separate, sealed silos. In fact, the regulated system produces no positive ripple effect on the unregulated one, which is reduced to functioning as a residual system.

The negative perception that students have of the open system, which they often disappointingly refer to as "faculty studies", is amplified by the depreciation so it is the object of some teachers themselves. It was also noted that half of the parents expect good academic performance and express concern about their behaviour, particularly among OAS students and female students.

We also found that the more parents expect their children to do well in university, the more their children look for new learning $(70 \%)$ and friends $(31.5 \%)$ in the 
university space. Indeed, the literature has often shown that parents, teachers, and society in general are more positive about the student's academic excellence than about the student's motivation to become more involved in his or her education [21,22]. Parents surveyed in a study conducted by the Higher Council of Education and Training (COSEF) in Morocco in 2008 on their preference for the system for their children, 49 percent of parents favored the regulated system, compared to 6 percent for the open faculty system. Knowing that in the OSS, 16.5 percent of students drop out in the first year of university and 47.2 percent drop out without graduating at the end of their education. Thus, some studies have shown a strong positive correlation between the cultural and economic level of the parents and the style of family education and the level of academic aspirations of the students [22,27].Thus, it has been supported by numerous studies that the positive participation of parents in their son's studies, and the quality of the teachers and the reputation of the school significantly affects students' academic performance and investment [23,28]. Particularly the work of Avvisati et al, [21], identified five key components of active parental involvement: constantly discuss with their children, strongly and continuously encourage them to excel in school, establish clear limits within the home, create a stimulating environment and accompany them home, follow up on how the children spend their time during the day.

On the other hand, in our sample, we have identified 15 types of difficulties that are sources of constraints on the efficiency of university student performance, and we have grouped them into three categories: cognitive difficulties (32.64\%), difficulties related to teaching methods (30.57 $\%)$ and the organization of the training program $(36.79 \%)$. Our results showed that one fifth of the students study every day. Female students spent significantly more time per day on course revision than their male counterparts. The majority of students reported starting exam preparation only in the last two weeks before the exam and thus spent an average of $6.50 \mathrm{hr} \pm 3.90 \mathrm{hr}$ per day. This hourly volume increases for females and for OAS students in unfavourable preparation conditions. Numerous studies have established a close relationship between perseverance (duration, repetition, intensity of work) and academic performance. This perseverance is expressed by the time spent learning and reviewing the knowledge acquired per module. It is thus one of the key elements of the sustainability of cognitive performance at the level of comprehension, memory, problem solving and production. All effective time planning should therefore take into account an optimal hourly volume by exceeding the daily constraints of academic life [25]. Therefore, students and pedagogical tutors should constantly control and monitor the effectiveness of the hourly volume of revision in all periods of the academic year. However, our results showed that half of the students were poorly satisfied $(52.1 \%)$ with their personal preparation methods $(56.5 \%)$ and felt that they were not very or not at all efficient (56.5\%).
Thus, students in the context of our study who do not find a completely adequate university curriculum, will be frustrated, demotivated because of the lack of orientation and pedagogical support and thus end up dropping out and abandoning their studies [27]. According to the OECD [29] report, the profile of academic excellence is distinguished among learners by the ability to learn quickly, easily and effectively. Thus, excellent students are highly attentive and vigilant, and are characterized by a high level of concentration and attention, identifying and using information efficiently. They obtain high marks in most modules, are continuously motivated to progress and develop, are very ambitious and have a spirit of discovery. These students are persistent and have a high level of energy, they enjoy studying in courses that match their preferences in asking many questions to understand and criticize constructively. In terms of the preparation strategies adopted by students, our results identified that female students review several modules per day (parallel mode), while male students adopt a serial preparation strategy (one module in 1-3 days).

Our results also showed that our sample adopted six preparation methods, dominated by reading and summarizing lectures. It is accepted in the literature that revision strategies determine the degree, depth and durability of comprehension, memorization, recall, knowledge application, analysis and problem solving, etc. However, in our sample, these strategies only mobilized comprehension and memory. This could not always guarantee good academic results. With two weeks to go before the exam, faced with six courses, the knowledge of these students can only be superficial and unstable. Students who start early and assiduously benefit from their preparation, as is the case for the majority of the girls in our sample.

With regard to the daily organization of exam preparation, we also noted two modalities adopted by the students, either an alternative strategy between work and rest containing periods of $30 \mathrm{~min}-2 \mathrm{~h}$, or an intensive strategy during the whole day or the whole night (sleepless night) observed essentially among the boys. These strategies are far from implying good academic results and satisfaction on the part of the students themselves. This is the reason why more than half of the students interviewed are not very satisfied with their preparation methods and think that they are not very or not at all efficient in both training systems. The studies in the literature conclude that the high achieving students used more self-assessment strategies related to checking of their outcomes, planning, monitoring effectiveness, revising methods and exams management, than the low achieving students $[30,31]$. Other studies have shown that effective students are those who seek help when needed [32], manipulate their learning environments to meet their learning needs [33] and monitor their progress towards their goals $[34,35]$. All research in this area confirms that the use of a combination of cognitive and metacognitive strategies [36, 37], affective strategies [38], elaboration and organization strategies [5,39-41], 
with repetition strategies [37], optimise the revision process and the academic performance of the student. On the question of factors correlated with academic achievements, this study found that female students' academic grades in the baccalaureate and during university training are significantly higher than those of males. This result is a continuation of the high rates of girls $(69 \%)$ compared to boys (31\%) who obtain "Very good" grades in the baccalaureate, and success in competitive examinations in regulated access institutions, according to the reports of the Evaluation Commission of the Ministry of National Education, Vocational Training and Higher Education and Scientific Research in Morocco, published in the last decade.

The phenomenon of the massive success of the female students is becoming a very remarkable fact in the educational landscape of Morocco [42]. However, according to the 2016 OECD report, in 33 countries around the world [43], the gender performance difference tends to be small. Finland is the only European country, where females outperform males. These gender-differentiated results find their explanation in psychodynamic theory in which sublimation is a compensatory process in the face of frustrations and feelings of inferiority induced by education (Adler, 1911). Therefore, we suggest to pedagogues and educators of different institutions to make a proximity accompaniment in the education of boys and girls in order to ensure equal opportunities between the genders.

On the other hand, we have identified through our results, four types of significant factors varying academic results: Attitudinal and perception factors towards training are materialized by the importance given to the modules, the attachment to excellence, the estimation of the difficulty of the exams and the encouragement of the parents. Factors related to the effectiveness of the preparation strategy (continuous revision of the courses, the volume of time, early preparation, implementation of effective work methods and making extra efforts (consulting books, internet, etc.). Cognitive factors are related to the degree of comprehension and concentration during the course, memory capacity, mastery of the language and previous knowledge specific to each module. The assessment factors are related to the level of difficulty of the questions and the grading system. Indeed, in the literature, a large number of personal (cognitive and affective) and environmental characteristics (family, school and classroom related, etc.) have been identified that vary outcomes between students [44]. Thus, academic achievement is a complex phenomenon for which it is impossible to isolate a finite and limited number of factors.

\section{CONCLUSION}

Our results showed that students' main concerns towards the university space are multiple and with qualitative and quantitative shifts between the two training systems: pluralist OAS vs. elitist RAS. Through our results, we can conclude on the interaction of the effect of the nature of the concerns, the effect of the university training system, and the effect of the parental style on the involvement, engagement and results of the student in his university training. Gender differences become more pronounced with the nature of the system. Males underestimate their abilities, are under-coached by their parent, less engaged in academic work, and underperform compared to their female counterparts. Effective strategies for exam preparation require optimizing study conditions, time involvement, and choosing methods that have tangible effects on academic performance. It is necessary to improve the attractiveness and flexibility of the training offer, especially in OAS, through soft skills, opening activities, welcoming structures, effective tutoring and pedagogical monitoring of students, especially in the first two years, with bridges between training programs.

\section{REFERENCES}

[1] Araújo, S. L., A. Cruz, J. F., \& S. Almeida, L. (2009). Pathways of excellence in science and dance: Lessons learned from a Portuguese case study. In International Symposium on Performance Science. Consulté à l'adresse http://www.performancescience.org/Publications/

[2] Gagné, F. (2004). Transforming gifts into talents: The DMGT as a developmental theory1. High Ability Studies, 15 (2), 119-147. https://doi.org/10.1080/1359813042000314682

[3] Renzulli, J. S. (2002). Emerging Conceptions of Giftedness : Building a Bridge to the New Century. Exceptionality, 10(2), 67-75. https://doi.org/10.1207/S15327035EX1002_2

[4] Monteiro, S., Almeida, L. S., Vasconcelos, R. M., \& Cruz, J. F. A. (2014). Be(com)ing an excellent student: A qualitative study with engineering undergraduates. High Ability Studies, 25(2), https://doi.org/10.1080/13598139.2014.966066

169-186.

[5] Boulet, Albert, Lorraine Savoie-Zajc et Jacques Chevrier. 1996. Les stratégies d'apprentissage à l'université. SainteFoy: Presse de l'Université du Québec. 201 p.

[6] Antoni Perez-Poch ; David López. 2017. Just-in-time teaching improves engagement and academic results among students at risk of failure in computer science fundamentals. IEEE Frontiers in Education Conference (FIE), 18-21 Oct. 2017, Indianapolis, IN, USA. DOI: 10.1109/FIE.2017.8190585

[7] Özüdoğru, Fatma. Evaluation of the voluntary english preparatory program at a turkish state university.Journal of International Social Research . Feb2017, Vol. 10 Issue 48, p501-509. 9p.

[8] Florentina Mogonea, Florentin Remus Mogonea. Requirements and modalities of ensuring success in academic learning, Educatia 21 Journal, $\mathrm{N}^{\circ} 16 / 2018$. DOI:1024.193/ed21.

[9] Santa Suarez . The Makings of 21st Century Learners: Correlation between the Learning Style and Achievement Level of Grade Six Students of Tanauan South Central School. Future Ed Special Edition: Multidisciplinary Research Journal VOL. 05 NO. 01 | 61. DECEMBER 2018. 60-69.

[10] Mohammed-Aminu Sanda. Dynamics of goal characterization in students' exams-preparation systemic activity transition processes. Theoretical Issues in Ergonomics Science Volume 21, 2020 - Issue 1 Pages 112130. DOI:10.1080/1463922X.2019.1658243.

[11] Fiorilli, C, De Stasio, S, Di Chiacchio, et al 2017, School burnout, depressive symptoms and engagement: Their 
combined effect on student achievement. International ,Journal of Educational Research, No. 84, Pp.1-12.

[12] Perrenoud, Ph. (1987). Sociologie de l'excellence ordinaire. Diversité des normes et fabrication des hiérarchies. Autrement, pp. 63-75

[13] Logan, M. R. et Skamp, K. R. (2013). The impact of teachers and their science teaching on students' 'science interest': A four-year study. International Journal of Science Education, 35(17), 2879-2904.

[14] Bouchard, P. et J.-C. ST-Amant (1996). Garçons et filles, stéréotypes et réussite scolaire. Montréal, Les Éditions du remue-ménage.

[15] Boudoukha A., Bonnaud-Antignac A., Aciera D, Chailloua A. Anxiété et stress, 2011. impact de la préparation du concours de pharmacie. Journal de Thérapie Comportementale et Cognitive. Volume 21, Issue 3, September 2011, Pages 90-96.

[16] Karilaa L., Seringeb E., Rouprêtc M., Peltierd M., Doulakid M., Goumontd M., Loyezd C., 2011. Lefèvre J.-H. Quels sont les facteurs prédictifs d'être reçu dans les 500 premiers à l'examen classant national (ECN) ? Une étude transversale au sein des étudiants en médecine de la promotion 2009. La Revue de médecine interne 32 (2011) 400-405

[17] Deslandes, R. et Potvin. P., 1998. Le milieu familial et la réussite éducative des adolescents in Bulletin du CRIRES, pp $1-4$.

[18] Deslandes, R. et Lafortune, L., 2001. La collaboration ÉcoleFamille dans l'apprentissage des mathématiques selon la perception des adolescents in revue des sciences de l'éducation vol. XXVII, \#3 pp 649-669.

[19] Deslandes, R. et Bertrand, R., 2003. L'état d'avancement des connaissances sur les relations École-Famille : Un portrait global. In vie pédagogique \#216 pp 27-29.

[20] Deslandes, R. et Cloutier, B., 2005 Pratiques parentales et réussite scolaire en fonction de la structure familiale et du genre des adolescents in revue Française de pédagogie, No : $151 \mathrm{pp} 61-72$.

[21] Avvisati, F. et al. (2014), « Getting parents involved: A field experiment in deprived schools ", The Review of Economic $\begin{array}{llll}\text { Studies, vol. } & 81 / 1, \quad \text { pp. }\end{array}$ https://doi.org/10.1093/restud/rdt027.

[22] Maltby, J; Day, L; Macaskill, A. (2007). Personality, Individual Differences and Intelligence. Pearson Education, $\mathrm{p}=87$.

[23] Archer, L; Dewitt, J; Osborne, J . (2015). Is science for us? Black students' and parents' views of science and science careers. Science Education, vol. 99/2, pp=199-237.

[24] Berelson, Bernard (1952). Content Analysis in Communication Research. Glencoe, Ill: Free Press

[25] Cervone, D; Caprara, V .(2000). Personality: Determinants, Dynamics, and Potentials. Cambridge University Press. $\mathrm{p}=348$.

[26] Pritz, A .(2008). Einhundert Meisterwerke der Psychotherapie. Wien (Osterreich): Springer.

[27] Kashefpakdel, E. T. and C. Percy (2016), "Career education that works: An economic analysis using the British Cohort Study", Journal of Education and Work, pp. 1-18.

[28] Brody, N. (2003). Construct validation of the Sternberg Triarchic Abilities Test: Comment and reanalysis. telligence, vol. 31, no 4, $\mathrm{p}=319-329$.

[29] Organisation for Economic Co-operation and Development (OECD). PISA, 2015. Excellence et l'équité dans l'éducation. Vol. 1. Paris: Organisation for Economic Co-operation and Development Archives.

[30] Sundre, D., \& Kitsansas, A. (2004). An exploration of the psychology of the examinee: Can examinee self-regulation and test taking motivation predict consequential and non- consequential test performance? Contemporary Educational Psychology, 29, 6-26.

[31] Merki, K. M. (2011). Effects of the implementation of state wide exit exams on students self-regulated learning. Studies in Educational Evaluation, 37, 196-205.

[32] Pintrich, P. R. (1995). Understanding self-regulated learning. New Directions for Teaching and Learning, 63, 3-12.

[33] Kolovelonis, A., Goudas, M., \& Dermitzaki, I. (2011). The effect of different goals and self-recording on self-regulation of learning a motor skill in a physical education setting. Learning and Instruction, 21(3), 355-364.

[34] Zimmerman, B. J., \& Kitsantas, A. (2014). Comparing students' self-discipline and self-regulation measures and their prediction of academic achievement. Contemporary Educational Psychology, 39(2), 145-155.

[35] Cleary, T. J., \& Zimmerman, B. J. (2004). Self-regulation empowerment program: A school-based program to enhance self-regulated and self-motivated cycles of student learning. Psychology in the Schools, 41(5), 537-550.

[36] Larue, C. (2005). Les stratégies d'apprentissage des étudiantes dans un cours de soins infirmiers utilisant l'apprentissage par problèmes. Université de Montréal (Canada): Thèse doctorale en sciences de l'éducation, Faculté des études supérieures en sciences de l'éducation.

[37] Larue, C., Hrimech, M. (2009). Analyse des stratégies d'apprentissage dans une méthode d'apprentissage par problèmes : le cas d'étudiantes en soins infirmiers. Revue internationale de pédagogie de l'enseignement supérieur, vol.25, $\mathrm{pp}=2-12$.

[38] Lasnier, F. (2000). Réussir la formation par compétences. Québec (Canada): Guérin Éditeur Ltée.

[39] Jones, B. F. (1988). Text learning strategy instruction: guidelines from theory and practice. In C.E. Weinstein, E.T Goetz, and P.A. Alexander (Dir.): Learning and study strategies: issues in assessment, instruction, and evaluation. San Diego, California : Academic Press

[40] O’Malley, J. M., Russo, R. P., Chamot, A. U., and StewnerManzanares, G. (1988). Applications of learning strategies by students learning English as a second language. In C. E.Weinstein, E. T. Goetz, and P. A. Alexander (Dir.) : Learning and study strategies : issues in assessment, instruction, and evaluation. San Diego, California : Academic Press.

[41] Weinstein, C. E., and Mayer, R. E. (1986). The teaching of learning strategies. Dans M. C.

[42] Wittrock (Dir.) : Handbook of research on teaching. New York, New York : Macmillan.

[43] Organisation for Economic Co-operation and Development (OECD). 2018. Examens de l'OCDE du cadre d'évaluation de l'éducation: Maroc. Paris: Organisation for Economic Cooperation and Development Archives

[44] Organisation for Economic Co-operation and Development (OECD). 2016. Education at a Glance 2016: OECD Indicator. Paris: Organisation for Economic Co-operation and Development Archives.

[45] Araújo, S. L., A. Cruz, J. F., \& S. Almeida, L. (2011). A entrevista no estudo da Excelência: Uma proposta. Psychologica, (52), 253-280. 